\title{
Capacity Enhancement of Major Roadways In Ado-Ekiti, South- Western Nigeria
}

\author{
Abe, O.E. and Adam, J.O \\ Dept. of Civil Engineering, Federal Polytechnic, Ado-Ekiti, Nigeria.
}

\begin{abstract}
The persistent traffic congestion and the consequent delay at intersections resulting in increased operating cost, travel time, accident rate, loss of convenience and comfort, early depreciation rate of vehicles, more fuel consumption, increased maintenance case are the problems affecting both social and economic life in Ado-Ekiti. To enhance the capacity of roads in Ado Ekiti, the physical road factors on vehicular delay at intersection on 10 major roads were investigated. From the investigation, it was discovered that street trading and illegal parking occupy about 29.4\% of the available road width in most of the approaches to intersections. Most of the roads have no shoulder and the one that have failed to meet the required stipulated standard of $2 \mathrm{~m}$. The capacity of major roads in Ado-Ekiti can be enhanced if parking facilities and bus terminals are provided and sited outside the right of way at regular intervals on both sides of the roadway. Pedestrian crossing and over-head pedestrian bridges should be provided at strategic locations. Road signs and traffic signals should also be provided at major intersections to ensure free flow of traffic.

Keywords: Capacity, Enhancement, Roadways. Ado-Ekiti, Nigeria.
\end{abstract}

\section{Introduction}

Ado-Ekiti being a state capital is located in the southwest zone of Nigeria on latitude $52^{0} \mathrm{~N}$ and longitude $14^{\circ} \mathrm{E}$. Based on the official census count of 1991 and allowing a growth rate of $6.5 \%$, the population of Ado-Ekiti is estimated at about 450,000 . Ado-Ekiti is growing into a thickly populated town caused by the influx of civil servants, business people, presence of two tertiary institutions and establishment of branches of commercial banks which has led to increase in the inflow and out-flow of vehicles in the area. The increase in. number of inflow and out flow of vehicles plying the township roads without corresponding road development, led to traffic congestion in the town. Most of the road width, right of way, drainage width and depth are inadequate. Most of the roads have no shoulder and the ones that have failed to meet the required stipulated standard of $2 \mathrm{~m}$.

The chronic problem is believed to be caused by the wide-spread of motor car and increased reliance on trucks for transporting. A study of transportation patterns in cities of developing countries revealed that many large cities have allowed a dense pattern of development that complicates the process of providing roads and public transportation services to urban residents. (Oyedepo, 2006).

One of the elements requiring the attention of the traffic engineer is the pedestrians, particularly in urban centers. The pedestrians present an element of sharp conflict with vehicular traffic, resulting in high accident rates and traffic delay. Pedestrian control is greatly needed to minimize pedestrian-vehicle conflicts, vehicle delay in order to maximize pedestrian safety. Pedestrian controls include sidewalks, cross walk pedestrian barriers, safety zones and islands, pedestrian turn and over passes, highway lighting and traffic enforcement control. (Vazirani and Chandola, 1984).

Cyclists regard themselves as equal to other road users, for the individual cyclist, it is a fast and cost effective means of travel. The advantages to other road users are that they do not .cause congestion; takes up little space on road and do not pollute the environment. Cyclists undermine their claim to be of equal status by a lack of regard for other road users, a failure to adhere to basic road safety guidelines, poor cycling behavior, poor perception and lack of courtesy towards others. (Lappin, 2000).

The driver deficiencies contribute to almost every accident on the roadway. Physical limitations, however account for only a small proportion of accidents, since slower and more careful driving could compensate for these limitations. Comparative studies between good and bad drivers, who were differentiated by their degree of involvement in traffic violations and accidents, reveal their psychological state (reaction time, vision, strength etc). Drivers and pedestrians often do not react to controls and regulators unless they appear reasonable. Some regulations that might appear to be unreasonable to the road users but are necessary' for safety must be back up by proper enforcement. (Whitlow, 1994).

It is seldom that traffic and roadway conditions are ideal, and therefore. Fundamental capacities must be decreased to take into, consideration the roadway and traffic factors that adversely affect traffic flow. The 
roadway factors are lane width, lateral clearance shoulders, pavement surface conditions, gradient, alignment and auxiliary lanes while the traffic factors, 'are type of vehicle, lane distribution, variation of traffic flow, on street trading, the street parking and traffic interruptions (O'flaherty, 1975)

Lane width:- $3.66 \mathrm{~m}$ lanes are considered ideal for heavy volumes of mixed traffic and a lane of narrower width will resist capacity. The width of lanes in Ado-Ekiti are narrower thus contributing to delays in major road and at intersections.

Lateral clearance: objects closer than $1.83 \mathrm{~m}$ from the edges of the pavement reduce the effective, width of the roadway. Lateral clearances are inadequate on roadways in Ado- Ekiti: thus reducing the effective width of the 'roadway.

Shoulders: Adequate shoulder of $2 \mathrm{~m}$ widths must be provided as refuge for stopped vehicles if capacities are to be maintained on the through lanes. Inadequate shoulders on roads in Ado-Ekiti has contributed to traffic delay.

Surface Conditions: poor pavement surface conditions may influence the attainment of required speed by drivers thereby affecting level of service and causing delay.

Gradient: 'A steep uphill gradient can significantly affect the acceleration rate of all vehicles when pulling away from road functions. Heavy vehicle speed also deteriorates on a combination of gradient and length of gradient.

Alignment: poor alignment prevents the attainment of required speed, thereby affecting capacity on two and three lanes roads when passing sight distance is restricted to less than $0.46 \mathrm{~m}$.

Auxiliary lanes: These include parking lanes speed change lanes, turning and storage lanes, weaving lanes and truck-climbing lanes. Each of these lanes provide additional pavement width to accommodate special uses, helping to maintain the capacity of the through roadway. These auxiliary lanes are not provided in Ado-Ekiti major roads and these have contributed to major delays.

Type of vehicle: Commercial vehicles under all condition take up more space than passenger cars, thereby causing delays and reduce capacity. Lane distribution and variation of traffic flow also affect capacity of roadway (Pignatario, 1973).

On-street trading: On-street trading limits the available space for traffic flow. It occupies parts of the road carriageways thereby leading to reduction in road capacity and sight distance. It increases delays and road way congestion.

On-street Parking: Most of the roads in Ado-Ekiti are not subject to any form of parking control. Angle parking, however interferes more severely with moving traffic than parallel parking and accident rates are higher on street parking in Ado-Ekiti carriage way, causes delay and reduce capacity.

Traffic Interruptions: Dumping of refuse and other loads on highway reduces highway capacity and hinder it form performing optimally. This study will establish how the physical factors of the road have contributed to delay and traffic congestion thus reducing capacity on major roads in Ado-Ekiti. This study will also determine the effect of road users on the capacity of major roadways in Ado-Ekiti. The result obtained from this study can be used to predict the impact of widening roadways as well as the impact of specific development. It can also be used for redesign major roads in Ado-Ekiti to meet changed traffic conditions and the millennium goals.

\section{Materials and Methods}

Ten major roadways in Ado-Ekiti were used for this study. The roads were designated as follows:

$\begin{array}{lcc}\text { Ajilosun-old garage road } & - & \text { A } \\ \text { Old Garage Okeyinmi Ojumose Road - } & \text { B } \\ \text { Ojumose - Post Office - Old Garage Road - } & \text { C } \\ \text { Post Office - Atikankan } & - & \text { D } \\ \text { Matthew junction - Irona road } & - & \text { E } \\ \text { Ojumose - Fajuyi - Textile road } & - & \text { F } \\ \text { Fajuyi - Adebayo Road } & - & \text { G } \\ \text { Ogbon-Ado-Post Office Road } & - & \text { H }\end{array}$


Mathew Road

Ajibade Road

$\begin{array}{ll}- & \text { I } \\ - & \text { J }\end{array}$

Physical road factors of the roads were measured by the use of measuring tape. The results are noted in table I. All the measurements were taken in metres. Reconnaissance survey of all the designated routes in Ado-Ekiti for detailed studies was carried out.

\section{Results and Discussion}

Table 1: Physical Road Factors of Major Roads in Ado-Ekiti

\begin{tabular}{|c|c|c|c|c|c|c|c|}
\hline Route & 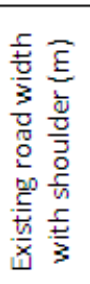 & $\begin{array}{l}\vec{E} \\
\frac{5}{5} \\
\frac{5}{3} \\
0 \\
0 \\
\frac{0}{0} \\
\frac{.}{0} \\
\frac{5}{0}\end{array}$ & 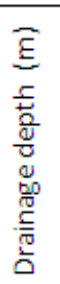 & $\begin{array}{l}\vec{E} \\
\frac{5}{5} \\
\frac{5}{3} \\
\frac{5}{5} \\
\frac{0}{0} \\
\frac{0}{2}\end{array}$ & 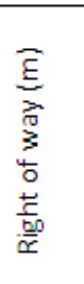 & $\begin{array}{l}\text { Space } \\
\text { occupied by } \\
\text { illegal } \\
\text { parking/stre } \\
\text { et trading } \mathrm{m}\end{array}$ & $\begin{array}{c}\text { Space } \\
\text { left for } \\
\text { traffic } \\
\text { flow }(\mathrm{m})\end{array}$ \\
\hline Ajilosun Old Garage Road & 9.2 & 0.8 & 0.8 & 0.67 & 18.4 & 3.0 & 15.4 \\
\hline Old garage Okeyinmi Ojumose road & 7.4 & 0.7 & 0.9 & - & 7.4 & 4.2 & 3.2 \\
\hline Old garage Post Office Old garage Road & 8.2 & 0.7 & 0.5 & - & 8.2 & 4.4 & 3.8 \\
\hline Post Office, Atikankan Road & 9.0 & 0.7 & 0.9 & - & 9.0 & 4.0 & 5.0 \\
\hline Mathew Junction, Irona Road & 13.0 & 0.6 & 0.6 & 0.67 & 22.2 & 3.6 & 18.6 \\
\hline Ojumose-Fajuyi-Textile Road & 9.2 & 0.8 & 0.7 & 0.88 & 18.4 & 3.2 & 15.2 \\
\hline Fajuyi-Adebayo Road & 8.1 & 1.6 & 1.4 & 0.67 & 17.8 & 3.0 & 14.8 \\
\hline Ogbon Ado, Post Office & 7.2 & 0.7 & 0.6 & - & 7.2 & 4.2 & 3.0 \\
\hline Mathew Road & 14.3 & 0.7 & 0.5 & - & 14.3 & 4.6 & 9.7 \\
\hline Ajibade Lane & 7.2 & 0.8 & 0.9 & - & 7.2 & 4.0 & 3.2 \\
\hline & & & & & 130.1 & 38.2 & 91.9 \\
\hline
\end{tabular}

Note: Packing space and walk path are not available on all the roads. The results of the data collected during the survey are noted in table I, from the table, it was discovered that:-

(i) No provision is made for walk path, parking space and auxiliary lane in all the roadways.

(ii) The roadways designated $\mathrm{B}, \mathrm{C}, \mathrm{D}, \mathrm{G}, \mathrm{H}$ and $\mathrm{J}$ have inadequate road width with shoulder. Since the standard road width with shoulder is $9.2 \mathrm{~m}$. Roadways $\mathrm{B}, \mathrm{H}$ and $\mathrm{J}$ have no provision for shoulders, while the provision of shoulders for $\mathrm{C}, \mathrm{D}$ and $\mathrm{G}$. are not adequate.)

(iii) Right of way of all the designated roadways fall below the Minimum standard of $24.4 \mathrm{~m}$ for dual carriage way on secondary and feeder roads according to AASHTO to policy on road design of highways (Salter, 1976).

(iv) About $29.4 \%$ of the total width of roadway are occupied by either Street trading or street parking, thereby leaving about $70.6 \%$ of the total width of roadway for traffic flow.

(v) The poor pavement surface conditions of the designated roadways in Ado-Ekiti.

\section{Conclusion}

The road capacity in the town was not fully utilized as a result of the varying impedance that arose from lack of proper traffic management; highway planning and design of the designated roadways in Ado Ekiti. Street parking, refuse dumping, drivers characteristics, road deterioration, cyclist, disregard of other road users, pedestrians crossing, roadway factors and traffic factor all contributed in no small way to reduce the capacity of roadway in Ado Ekiti metropolis.

\section{Recommendation}

To ensure improved and effective traffic flow in Ado Ekiti, traffic control infrastructure should be provided such as pavement markings road sign, warning signs and regulations, pedestrian control devices. Parking facilities, bus terminals and refuse disposal sites should be provided and compliance strictly enforced. Some of the major road should be redesign. There should be construction of overhead pedestrian bridge to control pedestrian crossing and accident on roads. Laws and rules guiding the proper use of roadway and punishment for defaulters should be enacted. Introduction of, signal-controlled pedestrians crossing de ice will also improve the traffic capacity of major roads in Ado Ekiti. 


\section{References}

[1]. Lappin J (2000): “Advance Information Traveler Service”. L H T. London Second Edition pg 32-40

[2]. O'flaherty, C.A. (1975): “Highway Engineering” $1^{\text {st }}$ Edition, Vol. 2 Butler and Tanner Ltd. London Pp. 82.

[3]. Oyedepo, J.O. (2006): "Capacity Analysis of Urban Roadways: A case study of Lagos Metropolis", Journal of Applied Science Vol. 9 No. 1 March 2006 p.p. 6122-6131.

[4]. Pignataro L.J. (1973). "Traffic Engineering Theory and Practice" 3rd Edition practice Hall Inc. Englewood cliffs New Jersey Pp. 56

[5]. Salter, R.1. (1976): "Highway Traffic Analysis and Design” 2nd Edition Macmillan, Education Ltd. Basong-stroke Hampshire RG

[6]. Vazirani, V.N and Chandola, S.P. (1984): “Highway and Soil Engineering” $1{ }^{\text {st }}$ Edition , Romesh Chandar Khanna, Delhi. Pp. 156.

[7]. Whitlow, R. (1995): “Basic Soil Mechanics” $3^{\text {rd }}$ Edition Addison Wesley Longman Ltd, Edinburgh Gate. Pp. 187. 